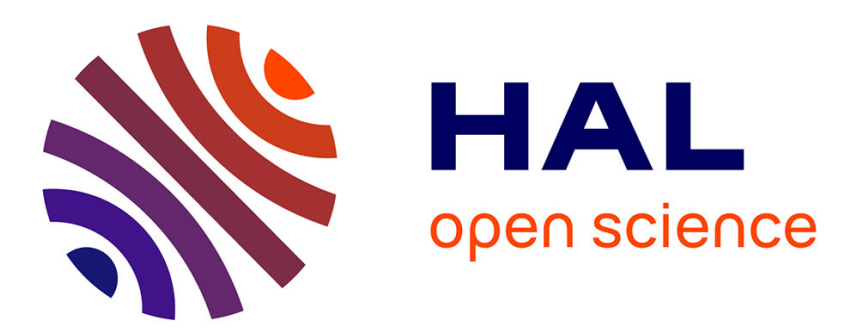

\title{
River ecosystem conceptual models and non-perennial rivers: A critical review 1
}

\author{
Daniel C Allen, T. Datry, Kate Boersma, Michael T Bogan, Andrew J. \\ Boulton, Daniel Bruno, Michelle H Busch, Katie H Costigan, Walter K.
} Dodds, Ken M Fritz, et al.

\section{To cite this version:}

Daniel C Allen, T. Datry, Kate Boersma, Michael T Bogan, Andrew J. Boulton, et al.. River ecosystem conceptual models and non-perennial rivers: A critical review 1. Wiley Interdisciplinary Reviews: Water, In press, 10.1002/wat2.1473 . hal-02905438

\section{HAL Id: hal-02905438 \\ https://hal.science/hal-02905438}

Submitted on 23 Jul 2020

HAL is a multi-disciplinary open access archive for the deposit and dissemination of scientific research documents, whether they are published or not. The documents may come from teaching and research institutions in France or abroad, or from public or private research centers.
L'archive ouverte pluridisciplinaire $\mathbf{H A L}$, est destinée au dépôt et à la diffusion de documents scientifiques de niveau recherche, publiés ou non, émanant des établissements d'enseignement et de recherche français ou étrangers, des laboratoires publics ou privés. 
Title. River ecosystem conceptual models and non-perennial rivers: A critical review

Running head. River ecosystem models and non-perennial rivers

3 Lead authors (in alphabetical order, both lead authors contributed equally to the conceptual

4 development of the manuscript, the review of the conceptual models, and co-wrote the initial

5 drafts of the manuscript):

6 Daniel C. Allen, Department of Biology, University of Oklahoma, Norman, OK, 73019, dcallen@ou.edu, Orcid: 0000-0002-0451-0564

8 Thibault Datry, INRAE, UR-RIVERLY, Centre de Lyon-Villeurbanne, 69626 Villeurbanne CEDEX, France, thibault.datry@inrae.fr ORCID: 0000-0003-1390-6736

Co-authors (in alphabetical order, all co-authors contributed to the review of the conceptual models and provided edits/comments to the manuscript):

Kate S. Boersma, Department of Biology, University of San Diego, San Diego, CA 92110 USA, kateboersma@sandiego.edu, Orcid:0000-0002-0707-3283

Michael T. Bogan, School of Natural Resources and the Environment, University of Arizona, Tucson, AZ 85716, USA, mbogan@email.arizona.edu, Orcid: 0000-0002-8150-8476

Andrew J. Boulton, School of Environmental and Rural Science, University of New England, Armidale, NSW 2350, Australia, aboulton@une.edu.au. Orcid: 0000-0001-7393-2800

Daniel Bruno, Department of Biodiversity and Restoration, Pyrenean Institute of Ecology (IPECSIC), Zaragoza, Spain,dbruno@ipe.csic.es, Orcid: 0000-0003-3976-9354

Michelle H. Busch, Department of Biology, University of Oklahoma, Norman, OK 73072 USA, buschmh@ou.edu,Orcid: 0000-0003-4536-3000

Katie H. Costigan, School of Geosciences, University of Louisiana, Lafayette, LA 70503 USA, costigan@louisiana.edu,Orcid:0000-0002-5706-7439

Walter K. Dodds, Division of Biology, Kansas State University, Manhattan, KS 66502 USA, wkdodds@ksu.edu, Orcid 0000-0002-6666-8930 
Sarah E. Godsey, Department of Geosciences, Idaho State University, Pocatello, ID 83209 USA, godsey@isu.edu, Orcid:0000-0001-6529-7886

Jeremy B. Jones, Institute of Arctic Biology and Department of Biology and Wildlife, University of Alaska Fairbanks, Fairbanks, AK 99775 USA. jay.jones@alaska.edu, Orcid: 0000-0003-35401392

Tatiana Kaletova, Department of Water Resources and Environmental Engineering, Slovak University of Agriculture in Nitra, 94976 Nitra, Slovakia. tatiana.kaletova@uniag.sk, Orcid: 00000003-2695-1448

Stephanie K. Kampf, Department of Ecosystem Science and Sustainability, Colorado State University, Fort Collins, CO 80523-1476 USA. stephanie.kampf@colostate.edu, Orcid:0000-

Meryl C. Mims, Department of Biological Sciences, Virginia Tech, Blacksburg, VA 24060 USA. mims@vt.edu, Orcid: 0000-0003-0570-988X

Thomas M. Neeson, Department of Geography and Environmental Sustainability, University of Oklahoma, Norman OK 73019 USA. neeson@ou.edu Oricid: 0000-0001-6758-0511

Julian D. Olden, School of Aquatic and Fishery Sciences, University of Washington, Seattle, WA, 98105, USA, olden@uw.edu Orcid:0000-0003-2143-1187

Amandine V. Pastor, CE3C, Centre for Ecology, Evolution and Environmental Changes, Faculdade de Ciências da Universidade de Lisboa, 1749-016 Lisboa, Portugal, avpastor@fc.ul.pt,.Orcid:0000-0003-4526-7705

N. LeRoy Poff, Department of Biology, Colorado State University, Fort Collins, CO 80523, USA, and Institute for Applied Ecology, University of Canberra, Canberra ACT 2617, Australia, poff@lamar.colostate.edu, Orcid: 0000-0002-1390-8742

Benjamin L. Ruddell, School of Informatics Computing and Cyber Systems, Northern Arizona University, Flagstaff, AZ 86004, USA, benjamin.ruddell@nau.edu Orcid: 0000-0003-2967-9339

Albert Ruhi, Department of Environmental Science, Policy, and Management, University of California, Berkeley, Berkeley, CA 94720, USA, albert.ruhi@berkeley.edu

Gabriel Singer, Leibniz-Institute of Freshwater Ecology and Inland Fisheries, Berlin, Germany, gabriel.singer@igb-berlin.de, Orcid:0000-0002-7389-9788

Paolo Vezza, Department of Environment, Land and Infrastructure Engineering, Politecnico di Torino, Italy, paolo.vezza@polito.it, Orcid:0000-0002-6784-8036

Adam S. Ward, O'Neill School of Public and Environmental Affairs, Indiana University, Bloomington, IN, 47405, USA, adamward@indiana.edu Orcid: 0000-0002-6376-0061 
Margaret Zimmer, Earth and Planetary Sciences, University of California, Santa Cruz, CA, 95064, USA, margaret.zimmer@ucsc.edu Orcid:0000-0001-8287-1923

\section{Abstract} on perennial rivers, those that always flow. Few explicitly address characteristics such as flow cessation and drying, which are becoming more prevalent in the Anthropocene. The applicability existing conceptual models to non-perennial rivers that cease to flow and/or dry (intermittent rivers and ephemeral streams, IRES) has not been evaluated. We reviewed 18 models, finding

93 that they collectively describe main drivers of biogeochemical and ecological patterns and

94 processes longitudinally (upstream-downstream), laterally (channel-riparian-floodplain),

95 vertically (surface water-groundwater), and temporally across local and landscape scales.

96 However, we also found that most of these models do not account for how different these

97 patterns and processes are for IRES. We suggest ways in which existing models could be modified to accommodate drying as a fundamental process that can alter these patterns and processes across spatial and temporal dimensions in streams. This perspective is needed to support river science and management in our era of rapid global change, including increasing duration, frequency, and occurrence of drying.

\section{MAIN TEXT.}

\section{Introduction}

Conceptual models underpin ecology. They identify ecological universalities across diverse taxonomies and geographies (Lawton, 1999). River ecosystem conceptual models have

107 historically focused on research from continuously flowing ("perennial") rivers to advance our

108 understanding of how hydrologic and geomorphologic processes structure river ecosystems.

109 Intermittent rivers and ephemeral streams (hereafter, "IRES") do not continuously flow, and

110 occur in all climates and biomes. They are extremely common in headwaters (Benstead \& 
111 Leigh, 2012), in regions with lower runoff (Dodds, 1997), and comprise at least half of global

112 river length (Datry et al., 2014). Moreover, rivers that freeze show some ecological and

113 hydrological parallels to IRES (Tolonen et al., 2019). IRES are ecologically and hydrologically

114 distinct from perennial rivers (Datry et al., 2017). So, are our existing riverine conceptual models

115 applicable to IRES?

116 Hydrological processes are foundational to river ecosystem conceptual models. Because

117 hydrological processes in IRES are marked by flow-cessation, drying, and rewetting phases,

118 conceptual models that embrace these processes would best represent IRES. A solid

119 foundation of IRES ecology research now exists (Datry et al., 2017), guided by conceptual work

120 on IRES ecology (Datry et al., 2014; Stanley et al., 1997) and hydrology (Costigan et al., 2016;

121 Godsey \& Kirchner, 2014). Thus, we are now well positioned to critically review river ecosystem

122 models and investigate how well IRES are represented in current river ecosystem conceptual

123 models.

124 River ecosystem conceptual models often guide river ecosystem management. If they

125 do not accurately depict a substantial fraction of the river network, management and policy

126 decisions could irreversibly harm rivers. River mismanagement examples are becoming

127 increasingly common as extreme droughts and drying events increase (Tonkin et al., 2019),

128 challenging water management strategies developed for perennial waterways (Shanafield et al.,

129 2020). Tools developed from existing conceptual models, such as biomonitoring approaches to

130 assess ecosystem integrity, are often ineffective in IRES (Stubbington et al., 2018). Similarly,

131 while the Natural Flow Regime conceptual framework (Poff et al., 1997) promoted the

132 implementation of environmental flows in river management (Richter \& Thomas, 2007), its

133 applicability in IRES is still uncertain (Acreman et al., 2014). Finally, environmental policies are

134 being redefined in the US and elsewhere to specifically exclude many IRES as waterways

135 warranting legal protection (Marshall et al., 2018). As IRES will likely become more dominant in 
136 the Anthropocene (Datry et al., 2014), understanding whether they are accurately described by

137 the conceptual models that underpin their management and legal protection is crucial.

138 Our paper reviews existing river ecosystem conceptual models to critically evaluate their

139 application to advance the science and management of IRES. We reviewed 18 influential

140 conceptual frameworks published between 1980 and 2016, classifying them into two broad

141 categories. The first category focuses on local- or reach-scale processes along the four major

142 hydrologic continua identified by the "Four-Dimensional Nature of Lotic Ecosystems" conceptual

143 framework by (Ward, 1989): longitudinal (upstream-downstream), lateral (channel-floodplain),

144 vertical (surface-subsurface), and temporal (variation over time). The second category

145 considers river networks at landscape and larger spatial scales, concentrating on the spatial

146 processes critical to the functioning of riverine ecosystems. We then assessed how well each of

147 these frameworks applied to IRES, and how IRES might challenge central assumptions of each

148 framework. Our findings lay the groundwork for a new perspective that includes river drying as a

149 fundamental component of riverine conceptual models that underpin present-day management

150 of river ecosystems.

River drying, flow cessation, and four-dimensional hydrologic continua at the reach scale

Longitudinal continuum. Six river conceptual models explicitly address the longitudinal

154 continuum of rivers (Table 1). As surface water flows downstream, it carries suspended organic

155 matter (Vannote et al., 1980) and dissolved nutrients (Fisher et al., 1998) used by micro- and

156 macro-organisms; most processed materials are exported downstream for further recycling.

157 This material processing is posited to occur continuously along the length of a river. Moreover,

158 riverine organisms can disperse among habitats along the upstream-downstream corridor.

159 Longitudinal continuum models focus explicitly on perennial rivers, but IRES challenge

160 the central assumption of continuous upstream-downstream connectivity. IRES are

161 longitudinally discontinuous at the surface when they dry (Figure 1). During dry periods, many 
162 IRES become isolated pools or ponds of standing water, or surface-disconnected reaches that 163 still flow (Figure 2). These disconnected pools and reaches are longitudinally isolated by dry 164 reaches upstream and/or downstream, preventing the downstream transport of materials in 165 surface waters (Pringle, 2001). Alternating expansion and contraction of wet stream reaches 166 over time drives nutrient and organic matter dynamics in IRES (von Schiller et al., 2017) and 167 controls population connectivity of riverine organisms (Allen et al., 2019).

168 Of these six models, only the Telescoping Ecosystem Model (Fisher et al., 1998)

169 addresses longitudinal expansion and contraction in a manner directly relevant for IRES, 170 probably because it draws heavily on research conducted in an IRES (Sycamore Creek, 171 Arizona, USA). The framework proposes that streams expand and contract longitudinally and 172 laterally from the river channel like the concentric cylinders of a telescope, constituting a key 173 physical process that controls nutrient dynamics in rivers (Fisher et al., 1998). This model has 174 not yet been applied to other IRES beyond this system, and a more extensive testing across a 175 range of systems would help in understanding its generality. Finally, we note that they River 176 Continuum Concept has been modified to accommodate IRES by some researchers (e.g. 177 grassland streams, (Dodds et al., 2004).

178 Lateral continuum. Six conceptual models emphasize lateral connectivity as a key factor 179 that structuring rivers ecosystems (Table 1). The expansion-contraction cycles of a river along 180 its lateral continua allow for bidirectional exchanges of organisms and materials between the 181 main and side channels, floodplains, and riparian zones. Below bankfull conditions, lateral river 182 expansion connects larger main channels with smaller side channels as flow increases (Flow 183 Pulse Concept, (Junk et al., 1989), which can both create river habitat (e.g. providing multiple 184 flow-paths through the river corridor) and homogenize it (e.g. water temperatures and nutrient 185 concentrations). During overbank flows, lateral river expansion connects river channels with 186 their floodplains (Flood Pulse Concept, (Tockner et al., 2000). Mobile riverine organisms can 187 then colonize inundated floodplains from the main channels, where they forage, spawn, and 
shelter from high water velocities of the main channel during a flood. The inundated floodplain becomes a source of nutrients for riverine biota that receive receding floodplain waters as flow returns to baseflow conditions.

This bidirectional exchange of organisms and materials along the lateral continuum does not always occur in IRES. When rivers are dry this exchange becomes primarily unidirectional because terrestrial organisms and material from riparian and floodplain habitats enter the

194 channel, whereas movement from channel to floodplains rarely occurs (Steward et al., 2017).

195 The duration of the dry period affects these lateral connections, controlling the decomposition 196 rates of leaf litter once the river rewets (Datry et al., 2018). IRES that flow for only a few days 197 after precipitation events may never produce sufficient adult aquatic insect emergence for 198 riparian predators, and mobile aquatic organisms such as fish that may temporarily inhabit 199 floodplains are rare in such rivers (Kerezsy et al., 2017). Thus, unidirectional lateral connectivity 200 may dominate IRES with short flow durations even when they have flow, except when heavy 201 rainfall events generate overbank flow (Zimmer \& McGlynn, 2017).

Despite IRES not conforming to our traditional understanding of the lateral continuum in 203 rivers, aspects of these six models are indirectly relevant. For example, IRES retract more than 204 perennial rivers along the lateral continuum, often to the point where no surface water remains. 205 The Flood Pulse Concept defines the floodplain as an "Aquatic-Terrestrial Transition Zone 206 (ATTZ)", where the expansion-contraction cycles depend on floods and the floodplain has 207 pronounced aquatic and terrestrial phases. Aquatic and terrestrial organisms may require 208 anatomical, morphological, physiological, and/or behavioral adaptations to colonize and persist 209 in the ATTZ (Junk et al., 1989). Thus, it is logical to extend the ATTZ from the floodplain to an 210 intermittent river channel where aquatic biota have evolved physiological and behavioral 211 adaptations that allow them to persist (Stubbington et al., 2017).

212 Vertical continuum. Two river ecosystem conceptual models focus on the vertical 213 continuum (Table 1). The vertical exchange of water, solutes, and organisms, can occur via 
214 downwelling of surface water into the hyporheic zone (the saturated subsurface zone beneath

215 the river channel) and upwelling of subsurface water into the river channel. The vertical

216 continuum is crucial for riverine biogeochemical cycles and organisms that link hyporheic and

217 benthic (riverbed) ecosystems. In most rivers, surface waters are mixed, oxygenated, and well-

218 lit, whereas the hyporheic zone is transport-limited, oxygen-deficient, and light-limited.

219 Hyporheic exchange of surface water- and groundwater-delivered material between these two

220 physically and chemically distinct environments promotes spatial heterogeneity in

221 biogeochemical transformations (Boano et al., 2014). Hyporheic exchange can also include

222 invertebrates, particularly those that can tolerate low dissolved oxygen conditions and feed on

223 ancient and methane-derived carbon sources in the hyporheic zone (DelVecchia et al., 2016).

Vertical continua and surface-subsurface exchanges are important in IRES, but in a

225 different way (Figure 1). In perennial rivers, hyporheic exchange is considered to occur

226 consistently through time (Boano et al., 2014). By contrast, hyporheic exchange in IRES is not

227 always continuous and may be unidirectional during drying (surface-to-subsurface only) and

228 rewetting (subsurface-to-surface only) phases (Zimmer \& McGlynn, 2017). Rewetting of some

229 IRES is driven completely by influxes of groundwater, delivering groundwater-derived material

230 and solutes into the river channel and causing rapid biogeochemical transformations (von

231 Schiller et al., 2017). Vertical exchanges of gases can also be important, and rewetting events

232 can initiate significant carbon dioxide effluxes from rivers to the atmosphere (Datry et al., 2018).

233 Drying rivers can be an important source of evaporative water vapor, and emissions from dry

234 channels can be higher than emissions through upland soils (Scanlon et al., 2006). Additionally,

235 the hyporheic zone can be an important refuge for benthic invertebrates during dry phases.

236 Recolonization from the hyporheic zone can be more important than aerial oviposition or larval

237 drift in structuring benthic community assembly after rewetting (Vander Vorste et al., 2016),

238 though hyporheic refuges can be less important in other systems when flow is reduced but

239 surface water still remains (James et al., 2008). 
241 mention IRES. (Stanford \& Ward, 1993) discuss "ephemeral springbrooks" that emerge during 242 spring runoff periods, usually in abandoned meander channels. Flow in springbrooks decreases 243 throughout the summer until surface water exists as pools connected by interstitial flow or the

244 channels dry completely. Connectivity along the vertical continuum was posited to be critical in

245 these dynamic systems (Stanford \& Ward, 1993), a prediction that has been supported in the

246 subsequent decades of research on IRES (Stubbington et al., 2017; Vander Vorste et al., 2016;

247 von Schiller et al., 2017).

248 Temporal continuum. Rivers are temporally dynamic as flow can vary greatly over time.

249 Five river conceptual models focus on the temporal continuum (Table 1), but each considers it

250 in a differently. (Ward, 1989) focuses on how organisms respond to temporal flow disturbances,

251 both behaviorally and evolutionarily. (Poff et al., 1997) describe the flow regime as "the

252 characteristic pattern of a river's flow quantity, timing, and variability" using a suite of flow 253 regime characteristics, such as flow magnitude, frequency, duration, timing, and rate of change.

254 (Wohl et al., 2015) extends this perspective to incorporate sediment input, transport, and 255 storage dynamics. The Pulse Shunt Concept (Raymond et al., 2016) highlights how low256 frequency, high-magnitude flow events are disproportionately important for dissolved organic 257 matter dynamics throughout entire river networks. The River Wave Concept (Humphries et al., 258 2014) integrates multiple river ecosystem conceptual frameworks according to temporal 259 variability in flow phase. It posits that the Flood-Pulse Concept (Junk et al., 1989) best explains 260 river ecosystem dynamics during peak flows, the River Continuum Concept is most relevant 261 during moderate flows (Vannote et al., 1980), and the Riverine Productivity Model (Thorp \& 262 Delong, 1994) applies best during baseflows.

263 The temporal continuum and its associated variation in flow phase are highly relevant in 264 IRES (Figures 2 \& 3). However, previous conceptual frameworks consider only flow variation 265 from baseflow at the lowest flow phase to overbank flood at the highest phase (Figure 3A-F). 
266 Flow phases between baseflow and complete drying occur in IRES (Figure 3E-G), but are not 267 discussed in previous frameworks (Costigan et al., 2016). As baseflow recedes in IRES, surface 268 flow stops, and stagnant, isolated pools may form. Surface water can disappear, but hyporheic 269 water remains; as drying continues, both surface and hyporheic water are lost. Each of these

270 flow phases is hydrologically and ecologically distinct, with different implications for hydrologic

271 and sediment transport, biota, and biogeochemical cycles (Costigan et al., 2016; Stubbington et

272 al., 2017; von Schiller et al., 2017). Importantly, variation in the duration, intensity, and

273 frequency of these different phases over time, and spatially throughout a river network, have

274 repercussions for biogeochemical and ecological processes. Therefore, we need to extend the 275 range of possible flow phases when considering IRES.

276 The Natural Flow and Sediment Regimes (Poff et al., 1997; Wohl et al., 2015) are

277 indirectly relevant to IRES. They center on temporal variability in flow and sediment dynamics in 278 riverine corridors and how these regimes have been modified by human activities. The Natural 279 Flow Regime notes that temporal variation in flow within single rivers can produce habitats that 280 range from free-flowing, through standing to no water, and IRES are briefly mentioned when 281 discussing low-flow conditions (Poff et al., 1997). Similarly, sediment regimes are the primary 282 drivers of valley-floor processes in non-perennial and perennial rivers; however, some 283 fundamental distinctions exist between them. In IRES, sediment flux and channel-bed grain size 284 distributions from upstream to downstream can differ substantially from those in perennial 285 streams (Jaeger et al., 2017). Thus, IRES can fit into the Natural Flow and Sediment Regime 286 frameworks with some further adjustments.

288 River drying and spatial processes and patterns

289 Nine river conceptual models focus on spatial processes and/or patterns, seeking to 290 explain how river ecosystems vary across landscape and larger scales (Table 1). The River 291 Continuum Concept (Vannote et al., 1980) and Riverine Productivity Model (Thorp \& Delong, 
292 1994) both propose that energy sources vary predictably according to river size and position 293 within the broader river network. In contrast, the Process Domains concept (Montgomery, 294 1999), Fluvial Landscape Ecology framework (Poole, 2002), Network Dynamics Hypothesis 295 (Benda et al., 2004) and the Riverine Ecosystem Synthesis (Thorp et al., 2008) emphasize the 296 patchy nature of the different stream habitat types that exist throughout a river network, as 297 hydrologic processes vary across space due to differences in watershed size, topography, and 298 geophysical characteristics. The Multiple Roles of Water framework (Sponseller et al., 2013) 299 describes water having three different ecological roles based on a river's position within the 300 broader river network: 1) as a resource and habitat in smaller rivers, 2) as a vector for 301 connectivity, and 3) as an agent of geomorphic change and disturbance in larger rivers. Finally, 302 the Stream Biome Gradient Concept (Dodds et al., 2015) and the following Freshwater Biome 303 Gradient framework (Dodds et al., 2019) present a framework for how river ecosystems should 304 vary geographically, across continental and global scales and across climate gradients and 305 biomes. These models specifically consider large geographic areas where intermittent or 306 ephemeral flow should occur with emphasis on the balance between potential and actual 307 evapotranspiration.

308 River drying adds a temporal dimension to spatial variation in river ecosystem habitats. 309 Drying is often a major driver of spatial heterogeneity in river networks (Figure 4). Flowing, non310 flowing, and dry reaches can exist anywhere throughout the network, occuring in headwaters, 311 tributaries, mainstems, and even river mouths. Moreover, (Costigan et al., 2016) suggest that 312 the typical locations of perennial and non-perennial sections in the river network may vary due 313 to differences in climate. In arid areas, perennial rivers are either very large mainstems that

314 drain wetter adjacent areas or small headwaters where perennial springs provide a constant 315 source of water; non-perennial sections can be anywhere. Conversely, in humid areas non316 perennial reaches are likely limited to headwaters, while downstream network reaches are 317 usually perennial (Costigan et al., 2016). Thus, the consideration of local drying regimes as 
318 another hydrologic layer in the landscape would complement the spatial heterogeneity we

319 typically consider within river networks and across biomes.

320 Two conceptual models focusing on spatial processes and patterns in streams are

321 relevant for IRES. IRES are a focus of the Multiple Roles of Water framework which discusses

322 how variation in flow permanence generates three types of river habitat: a pulse domain where

323 water may flow for minutes to weeks, a seasonal domain where water may flow for weeks to

324 months, and then a perennial domain where water continuously flows (Sponseller et al., 2013).

325 In this framework, flood-associated disturbances and hydrologic exchange are key drivers of

326 river ecosystem dynamics only when flow is perennial. (Sponseller et al., 2013) also discuss

327 how IRES are more abundant in arid regions, echoing the discussion in the Stream Biome

328 Gradient Concept (Dodds et al., 2015). Indeed, these are two of the most recent of the 18

329 conceptual models, and were developed by authors where IRES are common.

331 The need for a new ecohydrological perspective for river ecosystems

332 Our review reveals that most of these frameworks were designed for and derived from

333 research on perennial rivers. Yet IRES are equally as abundant worldwide, and climate change

334 and human water withdrawals are expanding IRES in space and time (Döll \& Schmied, 2012;

335 Grill et al., 2019). Accordingly, there is an imperative for a new perspective of river science: one

336 that emphasizes drying as an important hydrological process that structures river ecosystems.

337 Like existing river conceptual frameworks, such a perspective should be underpinned by

338 science. It should also empower adaptive management of rivers in the Anthropocene, along with

339 legislation and regulations regarding their environmental protection.

340 Below, we summarize the major points from our review that could form the basis of a

341 new ecohydrological perspective, which could be used to modify existing conceptual models to

342 account for IRES: 
1. Upstream and downstream hydrological connections along the longitudinal continuum occur in all rivers, but are usually episodic in IRES. During high-flow phases when the entire river network is flowing, the downstream transport of water, solutes, and organic matter predominates, and these materials are processed continuously as they move downstream. During low-flow phases, flows. During zero-flow phases, isolated stagnant pools behave more like lentic systems, and dry reaches become terrestrial and can be used by some organisms for migration (Bogan \& Boersma, 2012; Sánchez-Montoya et al., 2016).These transitions between phases underscore the need for collaboration among lotic, lentic, and terrestrial ecologists to more fully understand processes governing IRES (Datry et al. 2014).

2. Reciprocal linkages along the lateral continuum are essential to river ecosystems, but this exchange may be more unidirectional in intermittent rivers. While terrestrial-to-aquatic transfer of water, solutes, organic matter, and organisms are always important, the magnitude and potential importance of aquatic-to-terrestrial transfers decreases when the river is dry.

3. Except in bedrock rivers, connectivity along the vertical continuum is a fundamental riverine process, where water, solutes, and organisms are exchanged between the surface and the hyporheic zone. Again, this connectivity can become unidirectional (surface-to-subsurface) as rivers dry, or limited if the riverbed is entirely bedrock. Subsurface-to-surface connections are also important in IRES, especially when hyporheic influxes to the surface are the primary water delivery source during rewetting events. Often the hyporheic zone is a vital refuge for aquatic organisms during dry periods. 
4. Flow variation along the temporal continuum is pivotal because all natural rivers are dynamic and vary in phase over time. However, IRES have greater flow variation that includes zero flow, typically not included in river conceptual frameworks. The frequency, duration, and timing of these zero flows are critical in structuring riverine ecosystems, and must be considered in river research and management.

5. Spatial patterns in hydrologic processes create heterogeneity in abiotic conditions throughout a river network, in turn creating variability in riverine biotic processes. As drying governs hydrologic heterogeneity in space and time in IRES, drying should be specifically considered in river science and management.

6. IRES are threatened. They generally have less legal protection than perennial rivers due to the social undervaluation of their ecological attributes and ecosystem services (Marshall et al., 2018; Shanafield et al., 2020). They frequently serve as sites for trash dumping and sediment dredging, as conduits

\section{River drying and the Anthropocene} for waste water, and suffer severe hydrological alterations through artificial dewatering or augmented flows (Chiu et al., 2017). Artificially intermittent rivers are likely to differ ecologically from natural IRES, and these differences are relevant to effective management of these systems.

Drying is a fundamental hydrological process that structures river ecosystems in this era of rapid environmental change (Steffen et al., 2011). River drying is increasing across the globe

390 through climate change and increased human water extraction (Datry et al., 2014).

391 Temperatures will increase, leading to increased evapotranspiration and pushing systems 392 closer or beyond the balance where water losses to the atmosphere exceed inputs. Some areas 393 will become wetter and others drier under future climate scenarios, but increased climate 
394 variability is predicted to be widespread. The increased probability of dry periods (seasonal or

395 multi-year droughts) increases the probability of river drying. Dry river length has increased in

396 different regions due to the combined effects of drought, surface water extraction, and

397 groundwater pumping (Allen et al., 2019; Perkin et al., 2017). And as mentioned previously

398 freezing has some ecohydrological parallels to drying, and we know that river freezing regimes

399 are being altered due to climate change as well (Tolonen et al., 2019; Yang et al., 2020).

400 Moreover, IRES are among the types of freshwater systems most likely to experience

401 hydrological changes due to climate change (Dhungel et al., 2016).

402 Our review of 18 contemporary conceptual models of river ecosystems shows that

403 hydrological processes are fundamental in structuring stream ecosystems, but that drying has

404 rarely been considered. Given that IRES are already ubiquitous and becoming more common

405 due to global change, we argue that an expanded ecohydrological perspective for rivers is

406 urgently needed to guide current and future river research and management. IRES comprise a

407 significant component of the continuum of lotic waters, and a framework that explicitly

408 incorporates such habitats would better represent the true range of natural and artificial river

409 ecosystems. This new framework will facilitate adaptive management and protection of all rivers

410 rather than just those that continuously flow, and acknowledge flow cessation drying as a crucial

411 aspect of most flow regimes.

\section{Acknowledgements}

414 This manuscript is an international collaboration between SMIRES (Science and Management

415 of Intermittent Rivers and Ephemeral Streams, www.smires.eu, funded by COST [European

416 Cooperation in Science and Technology]), the Dry Rivers Research Coordination Network

417 (www.dryriversrcn.org, funded by the US National Science Foundation DEB-1754389), and

418 StreamCLIMES (sCaling cLimate connectlvity and coMmunitiES in Streams, funded by the US

419 National Science Foundation DEB-1802872) research groups. The opinions expressed are 
420 those of the researchers, and not necessarily the funding agencies. Although this work was

421 reviewed by the US Environmental Protection Agency and approved for publication, it might not

422 necessarily reflect official Agency policy.

423

424 References

425 Acreman, M., Arthington, A. H., Colloff, M. J., Couch, C., Crossman, N. D., Dyer, F., Overton, I., 426 Pollino, C. A., Stewardson, M. J., \& Young, W. (2014). Environmental flows for natural, hybrid, and novel riverine ecosystems in a changing world. Frontiers in Ecology and the Environment, 12(8), 466-473. https://doi.org/10.1890/130134

Allen, D. C., Kopp, D. A., Costigan, K. H., Datry, T., Hugueny, B., Turner, D. S., Bodner, G. S., \& Flood, T. J. (2019). Citizen scientists document long-term streamflow declines in intermittent rivers of the desert southwest, USA. Freshwater Science, 38(2), 244-256. https://doi.org/10.1086/701483

Benda, L., Poff, N. L., Miller, D., Dunne, T., Reeves, G., Pess, G., \& Pollock, M. (2004). The Network Dynamics Hypothesis: How Channel Networks Structure Riverine Habitats. BioScience, 54(5), 413-427. https://doi.org/10.1641/00063568(2004)054[0413:TNDHHC]2.0.CO;2

Benstead, J. P., \& Leigh, D. S. (2012). An expanded role for river networks. Nature Geoscience, 5, 678-679. https://doi.org/10.1038/ngeo1593

Boano, F., Harvey, J. W., Marion, A., Packman, A. I., Revelli, R., Ridolfi, L., \& Wörman, A. (2014). Hyporheic flow and transport processes: Mechanisms, models, and biogeochemical implications. Reviews of Geophysics, 52(4), 603-679. https://doi.org/10.1002/2012RG000417

$445 \quad$ https://doi.org/10.1899/12-066.1 
Chiu, M.-C., Leigh, C., Mazor, R., Cid, N., \& Resh, V. (2017). Anthropogenic Threats to Intermittent Rivers and Ephemeral Streams. In Intermittent Rivers and Ephemeral Streams (pp. 433-454). Elsevier. https://doi.org/10.1016/B978-0-12-803835-2.00017-6

Costigan, K. H., Jaeger, K. L., Goss, C. W., Fritz, K. M., \& Goebel, P. C. (2016). Understanding controls on flow permanence in intermittent rivers to aid ecological research: Integrating

Datry, T., Foulquier, A., Corti, R., Schiller, D. von, Tockner, K., Mendoza-Lera, C., Clément, J. C., Gessner, M. O., Moleón, M., Stubbington, R., Gücker, B., Albariño, R., Allen, D. C., Altermatt, F., Arce, M. I., Arnon, S., Banas, D., Banegas-Medina, A., Beller, E., ... Zoppini, A. (2018). A global analysis of terrestrial plant litter dynamics in non-perennial

Datry, T., Bonada, N., \& Boulton, A. (Eds.). (2017). Intermittent Rivers and Ephemeral Streams: Ecology and Management. Elsevier. https://doi.org/10.1016/C2015-0-00459-2

Datry, T., Larned, S., \& Tockner, K. (2014). Intermittent Rivers: A Challenge for Freshwater Ecology. BioScience, 64(3), 229-235. https://doi.org/10.1093/biosci/bit027

DelVecchia, A. G., Stanford, J. A., \& Xu, X. (2016). Ancient and methane-derived carbon subsidizes contemporary food webs. Nature Communications, 7, 13163. https://doi.org/10.1038/ncomms13163

Dhungel, S., Tarboton, D. G., Jin, J., \& Hawkins, C. P. (2016). Potential Effects of Climate Change on Ecologically Relevant Streamflow Regimes. River Research and Applications, 32(9), 1827-1840. https://doi.org/10.1002/rra.3029 Latitude, and Slope: A Global Perspective. Journal of the North American Benthological Society, 16(1), 162-168. https://doi.org/10.2307/1468248 
472 Dodds, W. K., Bruckerhoff, L., Batzer, D., Schechner, A., Pennock, C., Renner, E., Tromboni, 473 F., Bigham, K., \& Grieger, S. (2019). The freshwater biome gradient framework:

$474 \quad$ Predicting macroscale properties based on latitude, altitude, and precipitation.

$475 \quad$ Ecosphere, 10(7), e02786. https://doi.org/10.1002/ecs2.2786

476 Dodds, W. K., Gido, K., Whiles, M. R., Daniels, M. D., \& Grudzinski, B. P. (2015). The Stream

477 Biome Gradient Concept: Factors controlling lotic systems across broad biogeographic

$478 \quad$ scales. Freshwater Science, 34(1), 1-19. https://doi.org/10.1086/679756

479 Dodds, W. K., Gido, K., Whiles, M. R., Fritz, K. M., \& Matthews, W. J. (2004). Life on the Edge:

$480 \quad$ The Ecology of Great Plains Prairie Streams. BioScience, 54(3), 205-216.

$481 \quad$ https://doi.org/10.1641/0006-3568(2004)054[0205:LOTETE]2.0.CO;2

482 Döll, P., \& Schmied, H. M. (2012). How is the impact of climate change on river flow regimes related to the impact on mean annual runoff? A global-scale analysis. Environmental Research Letters, 7(1), 014037. https://doi.org/10.1088/1748-9326/7/1/014037

Fisher, S. G., Grimm, N. B., Martí, E., Holmes, R. M., \& Jones, Jr., Jeremy B. (1998). Material

Godsey, S. E., \& Kirchner, J. W. (2014). Dynamic, discontinuous stream networks: Hydrologically driven variations in active drainage density, flowing channels and stream order. Hydrological Processes, 28(23), 5791-5803. https://doi.org/10.1002/hyp.10310

Grill, G., Lehner, B., Thieme, M., Geenen, B., Tickner, D., Antonelli, F., Babu, S., Borrelli, P., Cheng, L., Crochetiere, H., Macedo, H. E., Filgueiras, R., Goichot, M., Higgins, J., Hogan, Z., Lip, B., McClain, M. E., Meng, J., Mulligan, M., ... Zarfl, C. (2019). Mapping the world's free-flowing rivers. Nature, 569(7755), 215-221. https://doi.org/10.1038/s41586-019-1111-9

Humphries, P., Keckeis, H., \& Finlayson, B. (2014). The River Wave Concept: Integrating River Ecosystem Models. BioScience, 64(10), 870-882. https://doi.org/10.1093/biosci/biu130 
498 Jaeger, K. L., Sutfin, N. A., Tooth, S., Michaelides, K., \& Singer, M. (2017). Geomorphology and Sediment Regimes of Intermittent Rivers and Ephemeral Streams. In Intermittent Rivers and Ephemeral Streams: Ecology and Management. Datry, T, Bonada, N, Boulton, J (eds). (pp. 21-49). Elsevier. https://doi.org/10.1016/B978-0-12-803835-2.00002-4

502 James, A. B. W., Dewson, Z. S., \& Death, R. G. (2008). Do stream macroinvertebrates use 503 instream refugia in response to severe short-term flow reduction in New Zealand $504 \quad$ streams? Freshwater Biology, 53(7), 1316-1334. https://doi.org/10.1111/j.13652427.2008.01969.x

506

507

508

509

510

511

512

513

514

515

516

517

518

519

520

521

522

523

Junk, W., Bayley, P. B., \& Sparks, R. E. (1989). The Flood Pulse Concept in River-Floodplain Systems. In Proceedings of the International Large River Symposium. Canadian Special Publication of Fisheries and Aquatic Sciences 106. Dodge, DP (ed.). (pp. 110-127). Candian Government Publishing Centre.

Kerezsy, A., Gido, K., Magalhães, M. F., \& Skelton, P. H. (2017). The Biota of Intermittent Rivers and Ephemeral Streams: Fishes. In Intermittent Rivers and Ephemeral Streams: Ecology and Management. Datry, T, Bonada, N, Boulton, J (eds). (pp. 273-298). Elsevier. https://doi.org/10.1016/B978-0-12-803835-2.00010-3

Lawton, J. H. (1999). Are There General Laws in Ecology? Oikos, 84(2), 177-192. JSTOR. https://doi.org/10.2307/3546712

Marshall, J. C., Acuña, V., Allen, D. C., Bonada, N., Boulton, A. J., Carlson, S. M., Dahm, C. N., Datry, T., Leigh, C., Negus, P., Richardson, J. S., Sabater, S., Stevenson, R. J., Steward, A. L., Stubbington, R., Tockner, K., \& Vorste, R. V. (2018). Protecting U.S. temporary waterways. Science, 361(6405), 856-857. https://doi.org/10.1126/science.aav0839

Montgomery, D. R. (1999). Process Domains and the River Continuum. JAWRA Journal of the American Water Resources Association, 35(2), 397-410. https://doi.org/10.1111/j.17521688.1999.tb03598.x 
524 Perkin, J. S., Gido, K. B., Falke, J. A., Fausch, K. D., Crockett, H., Johnson, E. R., \& Sanderson, J. (2017). Groundwater declines are linked to changes in Great Plains stream fish assemblages. Proceedings of the National Academy of Sciences, 114(28), 7373-7378. https://doi.org/10.1073/pnas.1618936114

Poff, N. L., Allan, J. D., Bain, M. B., Karr, J. R., Prestegaard, K. L., Richter, B. D., Sparks, R. E.,

Poole, G. C. (2002). Fluvial landscape ecology: Addressing uniqueness within the river discontinuum. Freshwater Biology, 47(4), 641-660. https://doi.org/10.1046/j.13652427.2002.00922.x

Pringle, C. M. (2001). Hydrologic Connectivity and the Management of Biological Reserves: A Global Perspective. Ecological Applications, 11(4), 981-998. https://doi.org/10.1890/1051-0761(2001)011[0981:HCATMO]2.0.CO;2

Raymond, P. A., Saiers, J. E., \& Sobczak, W. V. (2016). Hydrological and biogeochemical

Richter, B., \& Thomas, G. (2007). Restoring Environmental Flows by Modifying Dam Operations. Ecology and Society, 12(1). https://doi.org/10.5751/ES-02014-120112

542 Sánchez-Montoya, M. M., Moleón, M., Sánchez-Zapata, J. A., \& Tockner, K. (2016). Dry riverbeds: Corridors for terrestrial vertebrates. Ecosphere, 7(10), e01508. controls on watershed dissolved organic matter transport: Pulse-shunt concept. Ecology, 97(1), 5-16. https://doi.org/10.1890/14-1684.1 https://doi.org/10.1002/ecs2.1508

Scanlon, B. R., Keese, K. E., Flint, A. L., Flint, L. E., Gaye, C. B., Edmunds, W. M., \& Simmers, I. (2006). Global synthesis of groundwater recharge in semiarid and arid regions. Hydrological Processes, 20(15), 3335-3370. https://doi.org/10.1002/hyp.6335 Shanafield, M., Godsey, S., Datry, T., Hale, R., Zipper, S. C., Costigan, K. H., Krabbenhoft, C. A., Dodds, W. K., Zimmer, M. A., Bogan, M., Kaiser, K. E., Burrows, R. M., Hammond, J. 

C., Busch, M., Kampf, S., Mims, M. C., Burgin, A., \& Olden, J. D. (2020). Science Gets Up to Speed on Dry Rivers. Eos, 101, https://doi.org/10.1029/2020EO139902.

Sponseller, R. A., Heffernan, J. B., \& Fisher, S. G. (2013). On the multiple ecological roles of water in river networks. Ecosphere, 4(2), art17. https://doi.org/10.1890/ES12-00225.1

Stanford, J. A., \& Ward, J. V. (1993). An Ecosystem Perspective of Alluvial Rivers: Connectivity and the Hyporheic Corridor. Journal of the North American Benthological Society, 12(1),

Stanley, E. H., Fisher, S. G., \& Grimm, N. B. (1997). Ecosystem Expansion and Contraction in Streams. BioScience, 47(7), 427-435. https://doi.org/10.2307/1313058

Steffen, W., Grinevald, J., Crutzen, P., \& McNeill, J. (2011). The Anthropocene: Conceptual and historical perspectives. Philosophical Transactions of the Royal Society A: Mathematical, Physical and Engineering Sciences, 369(1938), 842-867. https://doi.org/10.1098/rsta.2010.0327

Steward, A. L., Langhans, S. D., Corti, R., \& Datry, T. (2017). The Biota of Intermittent Rivers and Ephemeral Streams: Terrestrial AND Semiaquatic Invertebrates. In Intermittent Rivers and Ephemeral Streams: Ecology and Management. Datry, T, Bonada, N, Boulton, J (eds). (pp. 245-271). Elsevier. https://doi.org/10.1016/B978-0-12-803835-

\section{4} 2.00008-5

Stubbington, R., Bogan, M. T., Bonada, N., Boulton, A. J., Datry, T., Leigh, C., \& Vander Vorste, R. (2017). The Biota of Intermittent Rivers and Ephemeral Streams: Aquatic Invertebrates. In Intermittent Rivers and Ephemeral Streams: Ecology and Management. Datry, T, Bonada, N, Boulton, J (eds). (pp. 217-243). Elsevier. https://doi.org/10.1016/B978-0-12-803835-2.00007-3

Stubbington, R., Chadd, R., Cid, N., Csabai, Z., Miliša, M., Morais, M., Munné, A., Pařil, P., Pešić, V., Tziortzis, I., Verdonschot, R. C. M., \& Datry, T. (2018). Biomonitoring of intermittent rivers and ephemeral streams in Europe: Current practice and priorities to 
enhance ecological status assessments. Science of The Total Environment, 618, 10961113. https://doi.org/10.1016/j.scitotenv.2017.09.137

578 Thorp, J. H., \& Delong, M. D. (1994). The Riverine Productivity Model: An Heuristic View of Carbon Sources and Organic Processing in Large River Ecosystems. Oikos, 70(2), 305308. JSTOR. https://doi.org/10.2307/3545642

Thorp, J. H., Thoms, M. C., \& Delong, M. D. (2008). The riverine ecosystem synthesis: Toward conceptual cohesiveness in river science / James H. Thorp, Martin C. Thoms and Michael D. Delong. (1st ed..). Academic Press/Elsevier.

Tockner, K., Malard, F., \& Ward, J. V. (2000). An extension of the flood pulse concept. Hydrological Processes, 14(16-17), 2861-2883. https://doi.org/10.1002/10991085(200011/12)14:16/17<2861::AID-HYP124>3.0.CO;2-F

Tolonen, K. E., Picazo, F., Vilmi, A., Datry, T., Stubbington, R., Pařil, P., Perez Rocha, M., \& Heino, J. (2019). Parallels and contrasts between intermittently freezing and drying streams: From individual adaptations to biodiversity variation. Freshwater Biology, 64(10), 1679-1691. https://doi.org/10.1111/fwb.13373

Tonkin, J. D., Poff, N. L., Bond, N. R., Horne, A., Merritt, D. M., Reynolds, L. V., Olden, J. D.,

Vander Vorste, R., Malard, F., \& Datry, T. (2016). Is drift the primary process promoting the Ruhi, A., \& Lytle, D. A. (2019). Prepare river ecosystems for an uncertain future. Nature,

598 Vannote, R. L., Minshall, G. W., Cummins, K. W., Sedell, J. R., \& Cushing, C. E. (1980). The 599 River Continuum Concept. Canadian Journal of Fisheries and Aquatic Sciences, 37(1), 600 130-137. https://doi.org/10.1139/f80-017 
601 von Schiller, D., Bernal, S., Dahm, C. N., \& Martí, E. (2017). Nutrient and Organic Matter 602 Dynamics in Intermittent Rivers and Ephemeral Streams. In Intermittent Rivers and 603 Ephemeral Streams: Ecology and Management. Datry, T, Bonada, N, Boulton, J (eds). 604 (pp. 135-160). Elsevier. https://doi.org/10.1016/B978-0-12-803835-2.00006-1 605 Ward, J. V. (1989). The Four-Dimensional Nature of Lotic Ecosystems. Journal of the North $606 \quad$ American Benthological Society, 8(1), 2-8. https://doi.org/10.2307/1467397

607 Wohl, E., Bledsoe, B. P., Jacobson, R. B., Poff, N. L., Rathburn, S. L., Walters, D. M., \& Wilcox, 608 A. C. (2015). The Natural Sediment Regime in Rivers: Broadening the Foundation for $609 \quad$ Ecosystem Management. BioScience, 65(4), 358-371.

610 https://doi.org/10.1093/biosci/biv002

611 Yang, X., Pavelsky, T. M., \& Allen, G. H. (2020). The past and future of global river ice. Nature, $612 \quad 577(7788), 69-73$. https://doi.org/10.1038/s41586-019-1848-1

613 Zimmer, M. A., \& McGlynn, B. L. (2017). Ephemeral and intermittent runoff generation 614 processes in a low relief, highly weathered catchment. Water Resources Research, 615 53(8), 7055-7077. https://doi.org/10.1002/2016WR019742 
618 Table 1. Summary table of the 18 river conceptual models that we reviewed. We classified

619 models into categories by their focus on one or more of the 4-dimensional hydrologic continua

620 (longitudinal, lateral, vertical, or temporal) or on spatial processes and patterns. We reviewed

621 models for their relevance to IRES: only 3 were directly relevant, the remaining 15 were either

622 indirectly relevant or were not relevant.

623

\begin{tabular}{|c|c|c|c|}
\hline Name & Category & IRES Relevance & Citation \\
\hline $\begin{array}{l}\text { River Continuum } \\
\text { Concept }\end{array}$ & $\begin{array}{l}\text { Longitudinal, Lateral, } \\
\text { Spatial }\end{array}$ & No & Vannote et al., 1980 \\
\hline $\begin{array}{l}\text { Serial Discontinuity } \\
\text { Concept }\end{array}$ & Longitudinal & No & $\begin{array}{l}\text { Stanford \& Ward, } \\
1993\end{array}$ \\
\hline Flood Pulse Concept & Lateral & Indirect & Junk et al., 1989 \\
\hline $\begin{array}{l}\text { 4-D Nature of Lotic } \\
\text { Ecosystems }\end{array}$ & $\begin{array}{l}\text { Longitudinal, Lateral, } \\
\text { Vertical, Temporal }\end{array}$ & No & Ward, 1989 \\
\hline $\begin{array}{l}\text { Hyporheic Corridor } \\
\text { Concept }\end{array}$ & Vertical & Yes & $\begin{array}{l}\text { Stanford \& Ward, } \\
1993\end{array}$ \\
\hline $\begin{array}{l}\text { Riverine Productivity } \\
\text { Model }\end{array}$ & Spatial & No & $\begin{array}{l}\text { Thorp \& Delong, } \\
1994\end{array}$ \\
\hline Natural Flow Regime & Temporal & Indirect & Poff et al., 1997 \\
\hline $\begin{array}{l}\text { Telescoping } \\
\text { Ecosystem Model }\end{array}$ & Longitudinal, Lateral & Yes & Fisher et al., 1998 \\
\hline Process Domains & Spatial & No & Montgomery, 1999 \\
\hline Flow Pulse Concept & Lateral & Indirect & Tockner et al., 2000 \\
\hline $\begin{array}{l}\text { Fluvial Landscape } \\
\text { Ecology }\end{array}$ & Spatial & No & Poole, 2002 \\
\hline $\begin{array}{l}\text { Network Dynamics } \\
\text { Hypothesis }\end{array}$ & Spatial & No & Benda et al., 2004 \\
\hline $\begin{array}{l}\text { Riverine Ecosystem } \\
\text { Synthesis }\end{array}$ & Spatial & No & Thorp et al., 2008 \\
\hline $\begin{array}{l}\text { Multiple Roles of } \\
\text { Water }\end{array}$ & Spatial & Yes & $\begin{array}{l}\text { Sponseller et al., } \\
2013\end{array}$ \\
\hline
\end{tabular}




\begin{tabular}{|l|l|l|l|}
\hline River Wave Concept & $\begin{array}{l}\text { Longitudinal, Lateral, } \\
\text { Temporal }\end{array}$ & No & $\begin{array}{l}\text { Humphries et al., } \\
2014\end{array}$ \\
\hline $\begin{array}{l}\text { Natural Sediment } \\
\text { Regime }\end{array}$ & Temporal & Indirect & Wohl et al., 2015 \\
\hline $\begin{array}{l}\text { Stream Biome } \\
\text { Gradient Concept/ } \\
\text { Freshwater Biome } \\
\text { Gradient Framework }\end{array}$ & Spatial & Indirect & $\begin{array}{l}\text { Dodds et al., 2015, } \\
2019\end{array}$ \\
\hline Pulse Shunt Concept & $\begin{array}{l}\text { Longitudinal, } \\
\text { Temporal, Spatial }\end{array}$ & No & Raymond et al., 2016 \\
\hline
\end{tabular}

624

625 
627 Figure 1. Longitudinal, lateral, and vertical continua in rivers. River conceptual models have

628 largely focused on flow phases when rivers are longitudinally connected (a), and when lateral

629 and vertical continua are bidirectional (c). IRES have dry phases that lead to longitudinal

630 disconnections (b) and unidirectional lateral and vertical continua (d). In b, surface water is

631 present in blue reaches and absent in brown reaches (channel is dry). In c and d, blue vs.

632 brown soil/sediments indicate saturated vs. unsaturated.
a) wetted river network, longitudinally connected
b) wet and dry river network, longitudinally disconnected
c) river cross-section at overbank flood stage, lateral and vertical continua bidirectional
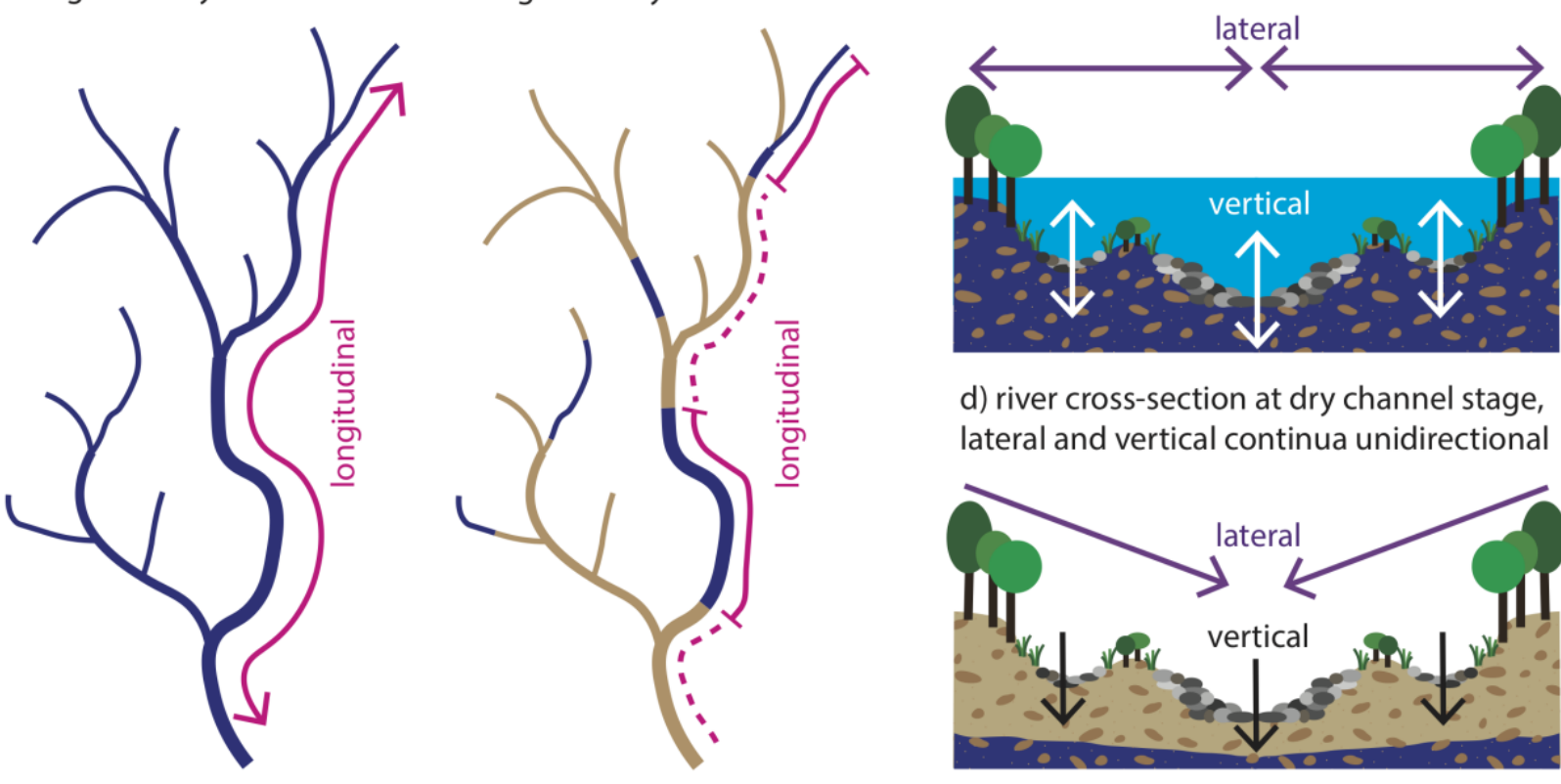

d) river cross-section at dry channel stage, lateral and vertical continua unidirectional

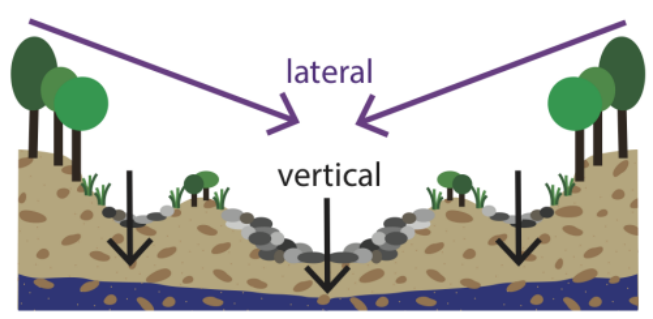


636 Figure 2. Alternating flowing (a), non-flowing (b), dry (c), and rewetting phases (d) in an

637 intermittent river (Calavon River, France). Photo credits: Bertrand Launay.

a. flowing

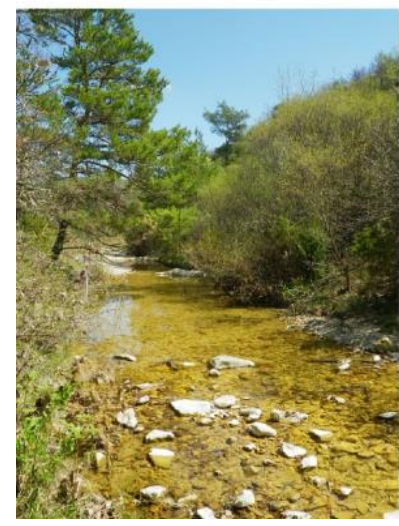

b. non-flowing

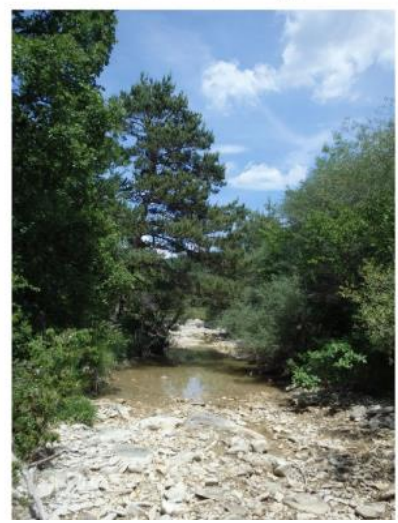

c. dry

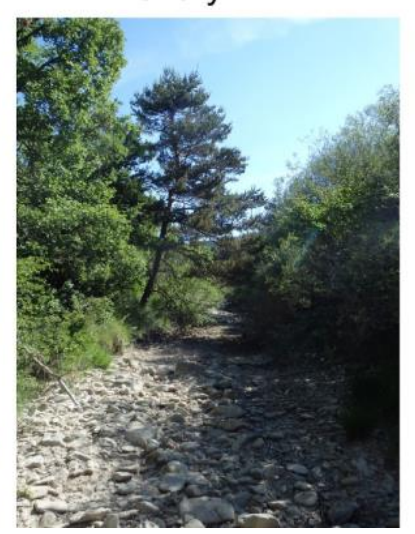

d. rewetting

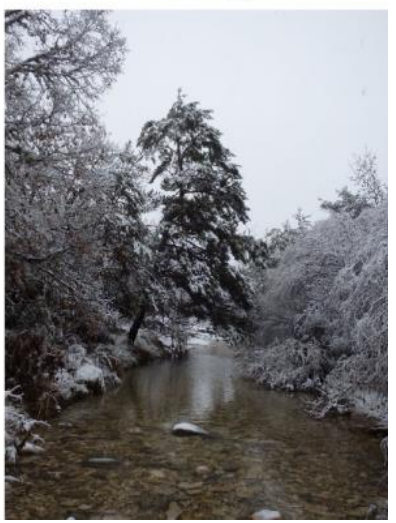


Figure 3. Temporal variation in flow phases in rivers. River conceptual models have largely

640 focused on the flowing "wet phases" between baseflow and overbank flows (panels a-f). IRES

641 have non-flowing dry phases (panels e-g) that are also important in structuring river

642 ecosystems. Blue vs. brown soil/sediments indicate saturated vs. unsaturated.

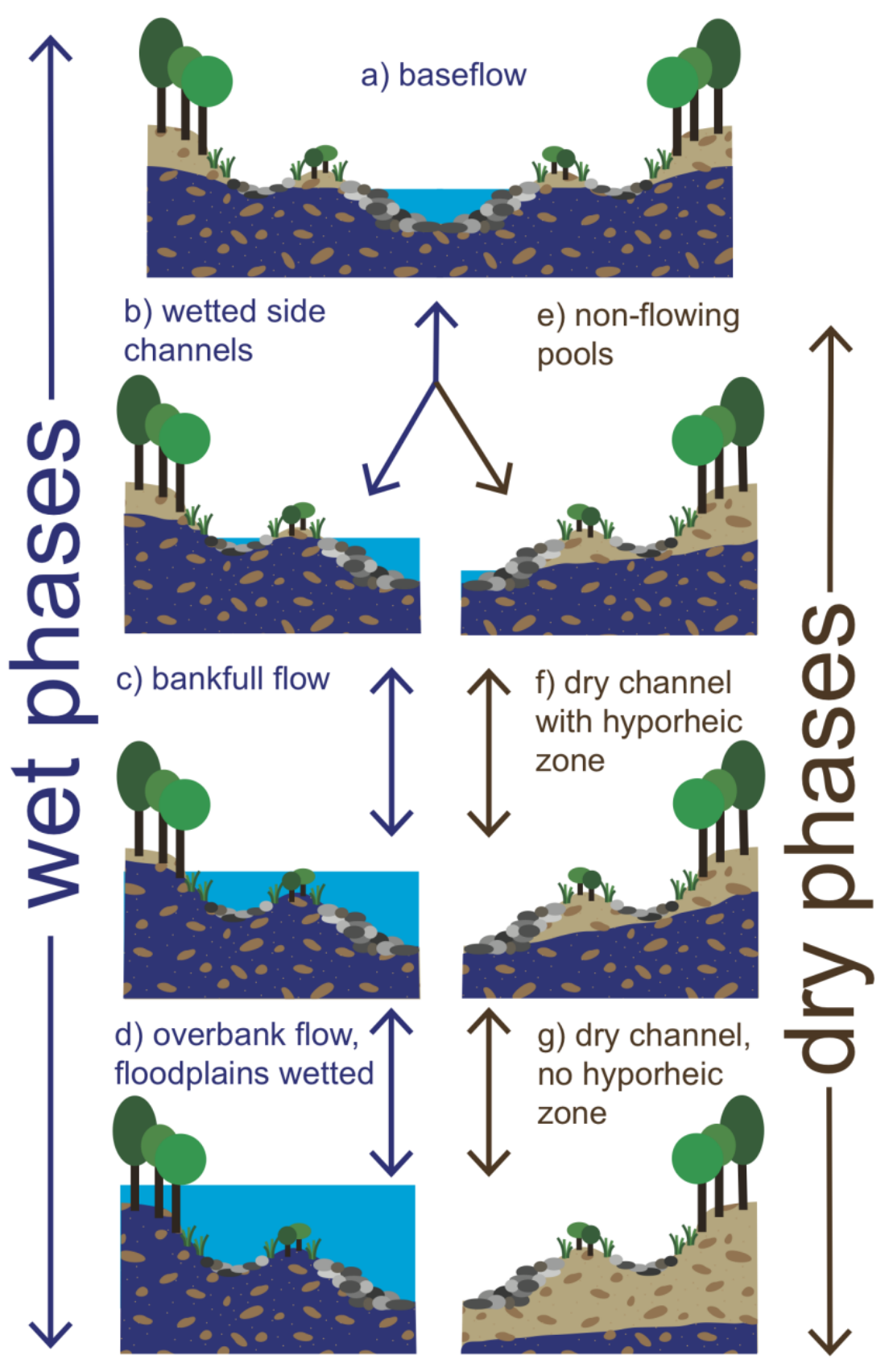


645 Figure 4. Temporal dynamism in spatial drying patterns in IRES networks. A) Within-year

646 variation in the Thouaret River, France, during the summer of 2012. Modified from (Datry et al.

647 2016). B) Between-year variation in Cienega Creek, Arizona, USA, (in the Natinoal

648 Conservation Area, NCA, and downstream) measured annually during the dry season from

649 2006-2016. Modified from (Allen et al. 2019).

\section{A) Thouaret River, France}
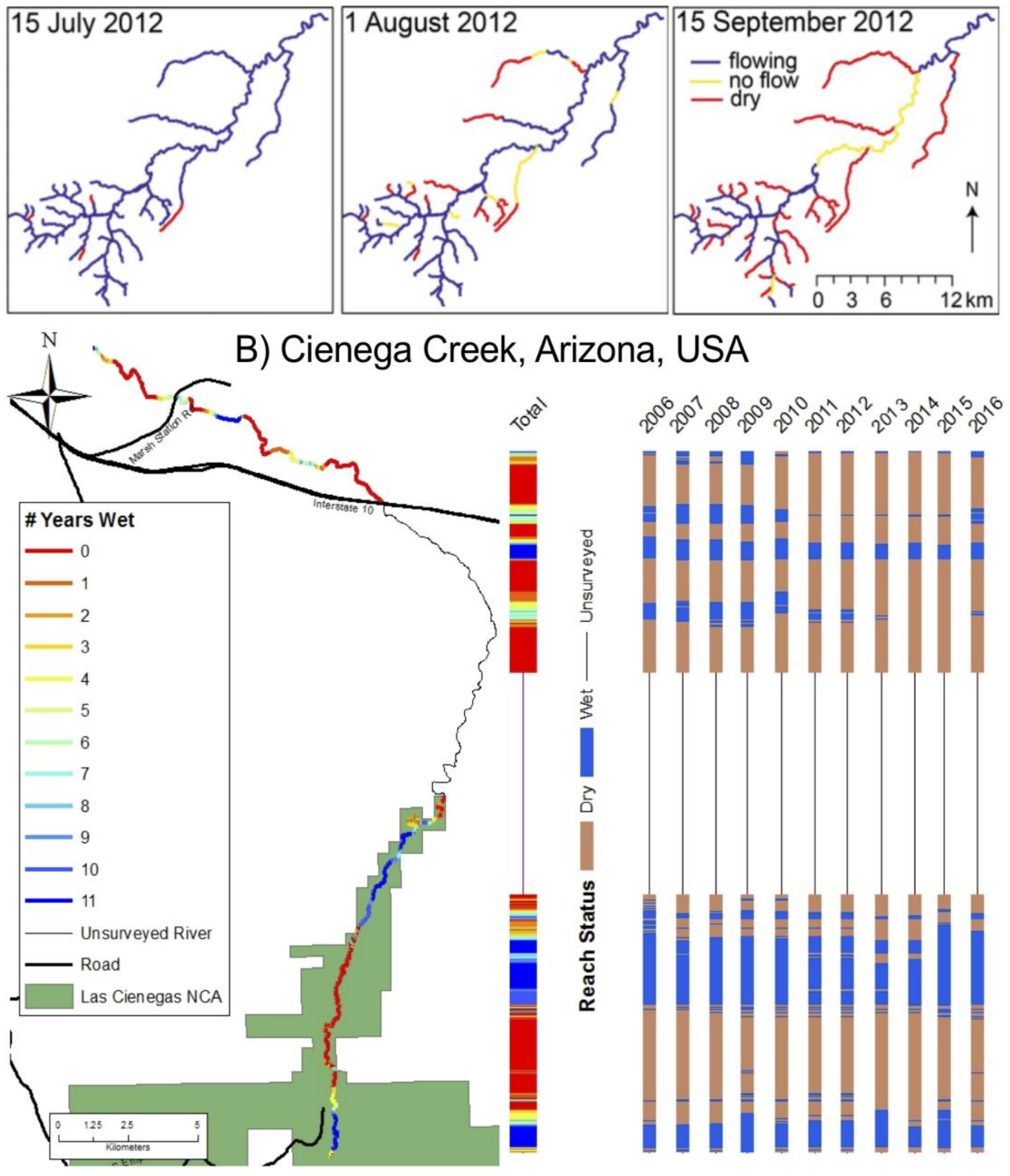